\title{
Survey of York University 1976-78 Bachelor's Degree Graduates in Psychology Located in Greater Toronto*
}

\author{
DAVID L. RENNIE $\dagger$
}

\begin{abstract}
A survey was made of 325 graduates who obtained a Bachelor's degree in psychology between 1976-78. It was found that (a) 73.5\% of the alumni were in the labour force, with the majority working in either parapsychological jobs, teaching, or business management; (b) the average salaries of the men and women were $\$ 14,610$ and $\$ 12,020$, respectively; (c) the unemployment rates for men and women were $9.8 \%$ and $6.1 \%$; (d) these rates were elevated by the rates for the 1978 graduates; and (e) $41.8 \%$ of the graduates went on to further training. The results are discussed in terms of the relevance of the Bachelor's degree in today's marketplace, and in terms of university programming in undergraduate education in psychology.
\end{abstract}

\section{RESUMÉ}

Un sondage fut effectué sur 325 diplòmé en psychologie ayant reçu leur baccalauréat (B.A.) entre 1976-1978 à York University. Les résultats ont indiqué que (a) $73.5 \%$ des diplômés étaient déjà sur le marché du travail où la majorité oeuvraient dans des emplois para-psychologiques, dans l'enseignement ou dans la gestion des affaires; (b) le salaire moyen était de \$14,610 pour les hommes et de \$12,020 pour les fermmes; (c) les taux de chômage étaient de $9.8 \%$ et $6.1 \%$ respectivement chez les hommes et les femmes; (d) ces taux étaient particulièrement élevés pour les diplômés de l'année 1978; et (e) 41.8\%.des diplômés avaient entrepris une formation subséquente. Une analyse fut également conduite au sujet de la demande qui existe actuellement sur le marché du travail pour un baccalauréat ainsi qu'à propos du développement des programmes d'études universitaires en psychologie au niveau du premier cycle.

\footnotetext{
* This study was supported by the Office of Admission, York University. Thanks are extended to Jeff Phillips, Elda Berti, Pat Doyle, Brian Walker, Janet Dodato and Wendy Yule, who assisted with the survey, and to Mirka Ondracek and Paul Herzberg, who helped set up the data analysis.
}

†Department of Psychology, York University 


\section{The Problem}

Undergraduates majoring in psychology are currently caught in a dilemma. On the one hand, they are attracted to psychology because of its intrinsic interest and because the prospect of a career oriented toward helping people is appealing. On the other hand, they are bombarded by press reports and editorials which, in Toronto, at least, call into question the usefulness of liberal arts education in today's society and endorse the technological training that community colleges can offer (see, for example, The Globe and Mail, December $1,1979)$. Despite all of this, large numbers of young people continue to register in Arts faculties and a good proportion of these continue to major in psychology.

What becomes of them after they graduate? Statistics Canada (1978a) found that the full-time employment rate of Canadian social science Bachelor's degree graduates who obtained their degrees in 1976 and who were surveyed two years later was six percent better than the national average and three percent lower than that of community college and technical school graduates of all types. These findings tend to dispel the notion that a liberal arts degree has no currency in the marketplace. However, the Statistics Canada survey was insufficiently fine-grained to allow one to determine exactly what types of jobs these graduates got. Ralston (1978) gained precise information about Saint Mary's University alumni who graduated in sociology between 1971 and 1977 . The present study examined the career outcomes of psychology majors who graduated with a Bachelor's degree between 1976 and 1978 and who were loca ted in Greater Toronto.

\section{METHOD}

\section{Population and sampling procedure}

It was decided that the best approach to surveying the alumni would be to telephone them. Since long-distance calls would have been prohibitively expensive, the calls were limited to those B.A. and B.Sc. graduates in psychology from the York University main campus and from the Glendon College (affiliate) campus who, at the time of the survey, could be reached without incurring long distance telephone costs. ${ }^{1}$ This district extended beyond the boundaries of Metropolitan Toronto and was estimated by Anisef and Jansen (Note 1) to be an area that produces $65 \%$ of the students in psychology. All of the male graduates from this Greater Metro area were included in the sample, while $50 \%$ of the female graduates were sampled. The 1976 and 1977 female alumnae were randomly sampled. Due to an inadvertent change in procedure, the 1978 women were sampled by choosing every second name on an alphabetized print-out of the graduates' names. This change in procedure was somewhat unfortunate, but not critically so, since the resultant systematic sampling is still considered a probability sampling procedure (Kerlinger, 1973, p. 130).

Three attempts were made to contact the respondent on the telephone. Different days of the week and hours of the day were used in these attempts to increase the chance of establishing contact. A supervisor phoned a randomly selected $5 \%$ of the respondents whom the five interviewers claimed to have contacted. This check was made to verify the claims. No evidence of false reports was found.

Each interviewer conducted the telephone interviews with the aid of an objective questionnaire. The same instrument was mailed to those members of the sample who could not be reached by telephone. The sample sizes for the 1976, 1977 and 1978 female graduates were 90,103 and 135 , respectively, while the corresponding breakdown 
for the men was 80,85 and 90 . The percentage contacted ranged from $50 \%$ for the 1976 male graduates to $61 \%$ for the 1976 female alumni. In all, 190 women (59\% of the sample) and 135 men $(53 \%)$ were contacted. The large majority of these respondents were between 22 and 31 years old, but the men tended to be older than the women. Forty-four percent of the men were between 22 and 25 , compared with $60.0 \%$ of the women. In contrast, $43.6 \%$ of the men were between 26 and 31 , as opposed to $27.9 \%$ of the women.

\section{Instrumentation}

The survey was structured by a 38 -item questionnaire (available upon request). In the report to follow, the results of the study reflect the structure of the questionnaire, with one exception. The questionnaire listed 55 occupations, and an "other" category, and asked the respondents to categorize their occupation according to this list. It was found that 11 of the occupations received no endorsement. For the purposes of analysis, the remaining 45 occupational categories were recoded into nine categories. The recoding was as follows: (1) teaching = administrator, college/vocational school teacher, elementary school teacher, secondary school teacher, supply teacher, special education teacher, fine arts teacher, physical education instructor/coach, or school counsellor; (2) business management $=$ industrial relations officer, management trainee, manager, supervisor, administrative assistant, junior executive, executive, senior official, or senior manager; (3) secretarial/clerical work = secretary, stenographer, typist, teller, cashier, bank clerk, statistics clerk, or teacher's aid; (4) psychotechnology = personnel officer, behavioural engineer, counsellor, daycare worker, group therapist, programme consultant, psychometrist, social case-worker, researcher, or statistician; (5) sales/supervision = sales person (commodities, including real estate), sales supervisor, and sales manager; (6) service $=$ janitor, labourer, policeman, security guard, postal worker, waitress, hostess, waiter, and steward; (7) nursing/lab technology = lab technician, nurse, or psychiatric nurse; (8) artistic/literary work $=$ artistic/literary worker, and writer; and finally, $(9)$ other $=$ other.

\section{Definitions of terms}

Statistics Canada (1978a, b) has defined several terms relating to employment, and the terms as used in the current report are based on these definitions. (1) The employed are persons who either did any work at all or who had a job but did not work during the week in which they were contacted because, of illness, personal reasons, and so on. (2) The unemployed are those persons who, during the reference week: (a) were without work but had actively looked for it in the past four weeks and were available for work; (b) had not actively looked for work in the past four weeks but had been on lay-off for the previous six months or less; or (c) had not actively looked for work in the past four weeks but had a new job to start in four weeks or less from the reference period, and were available for work. (3) The labour force is made up of both the employed and unemployed. (4) The full-time employed are those people who obtained 30 hours or more of work per week. (5) The unemployment rate is the number of unemployed persons divided by the number of people in the labour force. Finally, (6) the full-time employment rate is the number of full-time workers in relation to the labour force.

It can be seen that in terms of these definitions, people not actively looking for work and either part-time or full-time students who are not working, are not included in the labour force, and hence do not contribute to estimates of either the unemployment rate or the full-time employment rate. 


\section{RESULTS}

\section{The main choice: job or further training}

The main choice faced by individuals graduating with their first degree is whether to continue on with further training or to enter the labour force. Among the 325 people sampled, 65 out of 135 men (48.1\%) and 71 of 190 (37.7\%) women took further training after the Bachelor's degree. At the time of the survey, which was almost three years after the 1976 alumni graduated, $92(68.2 \%)$ of the men and $147(77.4 \%)$ of the women were in the labour force (three men and 13 women were unemployed and not seeking work and hence were not in the labour force). Thus of the 65 men who went on to further training, 40 were still engaged in it at the time of the survey and at least 22 of the remaining 25 were in the labour force. Alternatively, of the 71 women who took further training, 30 continued to do so at the time of the survey and at least 28 of the remaining 41 had entered the work force.

Thus, $51.9 \%$ of the men and $62.3 \%$ of the women elected not to pursue further training after graduating. The majority of them entered the labour force and, by the time of the survey, their ranks were increased by a number of individuals who had by then completed their post-Bachelor's degree training. In the report to follow, the author will first attend upon those who had entered the labour force by the time of the survey, and will then shift to the types of further training taken by those who did not immediately seek employment.

\section{Alumni in the labour force}

(a) Unemployment rates compared with Toronto rates. Table 1 shows that the unemployment rates of men and women during the autumn of their graduating year were $9.0 \%$ and $16.7 \%$, respectively, while at the time of the survey the respective rates were $9.8 \%$ and $6.1 \%$. How do the latter rates compare with the Toronto rates for the total labour force? Three computational steps were required in order to make the comparison. First, the August-October, 1978; February-March, 1979; and May, 1979 Toronto rates were prorated according to the proportion of respondents in the present survey who were surveyed during each of these times. Second, the Toronto rates were prorated according to the proportion of respondents in the current survey who fell into the Statistics Canada age categories (since, of course, the unemployment rates vary according to age). Third, the Toronto rates for men and women had to be estimated by adjusting the Ontario rate for each sex by the Toronto rate for both sexes combined (Statistics Canada does not tabulate Metropolitan area unemployment rates according to sex). The results were thus necessarily approximate. The Toronto unemployment rate as determined by this method was $5.7 \%$ and $7.0 \%$ for men and women, respectively.

The standard error for samples of the size used in the present survey is about $2.5 \%$. Hence, $95 \%$ of the time random sample proportions should be within $\pm 5 \%$ of the population proportions (i.e., the Toronto unemployment rates as determined by Statistics Canada). ${ }^{2}$ Accordingly, neither the unemployment rate for the York male graduates nor for the female graduates was significantly different from the Toronto rates.

However, a tabulation of unemployment rates according to the year the respondents graduated yields a different picture for the male graduates. The rates for the 1976, 1977 and 1978 graduates in this group were $3.5 \%, 3.0 \%$ and $22.5 \%$, respectively. The corresponding rates for the women were $4.3 \%, 6.0 \%$, and $7.8 \%$. When these rates were evaluated in terms of the standard error of the difference between sample proportions, the rate for 
Table 1

Main activity in the autumn of the graduating year and

at the time of the survey

\begin{tabular}{|c|c|c|c|c|}
\hline & \multicolumn{2}{|c|}{ Autumn of Grad Year } & \multicolumn{2}{|c|}{ Time of Survey } \\
\hline & M & w & M & w \\
\hline & $\underline{n}=135$ & $\underline{n}=190$ & $\underline{n}=135$ & $\mathrm{n}=190$ \\
\hline Worked full-time & $\begin{array}{c}72^{\mathrm{a}} \\
53.3 \%\end{array}$ & $\begin{array}{c}77 \\
40.5 \%\end{array}$ & $\begin{array}{l}74 \\
54.8 \%\end{array}$ & $\begin{array}{l}112 \\
58.9 \%\end{array}$ \\
\hline Worked part-time & $\begin{array}{c}9 \\
6.7\end{array}$ & $\begin{array}{c}23 \\
12.1\end{array}$ & $\begin{array}{c}9 \\
6.7\end{array}$ & $\begin{array}{c}26 \\
13.7\end{array}$ \\
\hline $\begin{array}{l}\text { Unemployed, sought } \\
\text { work }\end{array}$ & $\begin{array}{c}8 \\
5.9\end{array}$ & $\begin{array}{c}20 \\
10.5\end{array}$ & $\begin{array}{c}9 \\
6.7\end{array}$ & $\begin{array}{c}9 \\
4.7\end{array}$ \\
\hline $\begin{array}{l}\text { Unemployed, did } \\
\text { not seek work }\end{array}$ & $\begin{array}{c}4 \\
3.0\end{array}$ & $\begin{array}{l}13 \\
6.8\end{array}$ & $\begin{array}{c}3 \\
2.2\end{array}$ & $\begin{array}{l}13 \\
6.8\end{array}$ \\
\hline Full-time student & $\begin{array}{c}41 \\
30.4\end{array}$ & $\begin{array}{c}54 \\
28.4\end{array}$ & $\begin{array}{c}40 \\
29.6\end{array}$ & $\begin{array}{c}28 \\
14.7\end{array}$ \\
\hline Part-time student & $\begin{array}{c}1 \\
0.7\end{array}$ & $\begin{array}{c}3 \\
1.6\end{array}$ & $\begin{array}{l}0 \\
0\end{array}$ & $\begin{array}{c}2 \\
1.1\end{array}$ \\
\hline
\end{tabular}

a $I n$ this and the remaining tables, the first value in each category is the number of respondents in the category, and the second value is the column percentage of respondents.

the 1978 male graduates was significantly higher than the Toronto rate. The implications of these findings will be discussed later in the article.

(b) Full-time employment rate compared with that of 1976 Ontario graduates and Canadian social science graduates. A survey of Canadian college and university alumni who graduated in 1976 was conducted by Statistics Canada (1978a) during the week of May 28 to June 3, 1978. The investigators sampled $25 \%$ of the Ontario population of university and college graduates and contacted $71 \%$ of the sample. It was found that fulltime employment rates for Ontario Bachelor's degree graduates from all disciplines were $76.7 \%, 81.1 \%$ and $81.6 \%$ at 1 month, 18 months and 2 years after graduation, respectively. In terms of the national scene, as of June, 1978, there was an $87.0 \%$ full-time employment rate for social science alumni with a Bachelor's degree who graduated in 1976, and an $88.8 \%$ rate for the Bachelor's degree graduates in all disciplines (the full-time employment rate for all Canadians in the labour force irrespective of educational attainment was $81.0 \%$ ).

In contrast, the full-time employment rate for the 1976, 1977 and 1978 York psychology Bachelor's degree graduates was $87.8 \%, 75.9 \%$ and $70.7 \%$, respectively. Hence, the rate for the 1976 graduates was almost identical to the national rate for social science graduates for that graduating year. However, the comparison is not exact because the 1976 graduates in the present survey were contacted approximately 10 months after those 
contacted in the Statistics Canada survey, and neither the Ontario nor the Canadian comparison group is a precise match of the current one.

(c) Unemployment rates of Ordinary versus Honours degree graduates. Another finding of interest is that, contrary to what one might expect, the York graduates with a 4-year Honours degree were more unemployed than those with a 3-year Ordinary degree. For the men, 5 out of $63(7.9 \%)$ of the Ordinary degree holders were unemployed in comparison with 4 of $29(13.8 \%)$ of the Honours degree group, while for the women the values are 2 of $100(2.0 \%)$ and 7 of $47(14.9 \%)$. Calculation of the significance of the difference between two sample proportions (see footnote 3 above) indicates that the difference between the rates for the two groups of female graduates is statistically significant. One possible explanation for this discrepancy is that the female Honours graduates were more particular about the types of jobs they would accept.

(d) The job-hunting process and job obtained. Among those graduates who immediately entered the labour force after graduating, 78\% got their first job within a 3-month search period. These jobs were primarily obtained by contacts provided by friends or relatives $(22 \%)$, by answering advertisements $(21 \%)$, or by having worked for an employer previously $(17 \%)$. Only $11 \%$ got their job through the Canada Employment Service, and the remainder relied upon one of a variety of "other" ways of getting employment. It was found that $51 \%$ of them were employed by private enterprise, and $36.9 \%$ were employed by governments. The remainder were either self employed or worked for private funded agencies. In terms of the type of industry worked in, $32.0 \%$ worked in community, business or personal service, $29.8 \%$ worked in public administration, and $16.7 \%$ worked in the wholesale and retail trade. The rest were thinly distributed among several other categories of industries.

There was a trend wherein more women holding Honours degrees got work with municipal governments compared to women holding Ordinary degrees, likely because relatively more graduates with an Honours degree chose teaching as a career. On the other hand, the reverse was true for private enterprise concerns. Also, the men were significantly different from the women in the types of settings in which they worked. Proportionately more women than men worked in schools, whereas more men than women worked in "other" types of settings.

Tables 2 through 4 depict the type of work obtained by the respondents, the relevance of a university degree to the work, and the job satisfaction rates.

The main focus of interest here is the extent to which the possession of a degree elevated the kinds of jobs that the respondents could secure. As is evident from Table 2, the results are mixed. A number of respondents $(27.1 \%)$ obtained jobs in secretarial, service and sales work that, to a large extent, did not require a university degree as a condition of employment. At the same time, the apparent underemployment of these graduates did not have a direct relationship to job satisfaction. While the satisfaction expressed by the secretarial and service workers was, indeed, lowest among the nine categories of workers, the satisfaction expressed by the sales people and sales-managers was the highest.

On the other side of the coin, $60.4 \%$ of the respondents in the labour force got work in either psychotechnology, teaching, or business management, and $51.8 \%$ of these respondents indicated that a university degree was an essential requirement for employment. Among the business managers, while almost two-thirds of them registered that having a degree helped them to get a job, only slightly over one-fourth indicated that the degree 


\begin{tabular}{|c|c|c|}
\hline & $\begin{array}{c}M \\
n=85\end{array}$ & $\begin{array}{c}W \\
\underline{n}=140\end{array}$ \\
\hline Teaching & $\begin{array}{l}14 \\
16.5 \%\end{array}$ & $\begin{array}{c}34 \\
24.3 \%\end{array}$ \\
\hline Business Management & $\begin{array}{c}20 \\
23.5\end{array}$ & $\begin{array}{c}16 \\
11.4\end{array}$ \\
\hline Secretary/Clerical work & $\begin{array}{c}1 \\
1.2\end{array}$ & $\begin{array}{c}28 \\
20.0\end{array}$ \\
\hline Psychotechnology & $\begin{array}{c}16 \\
18.8\end{array}$ & $\begin{array}{c}36 \\
25.7\end{array}$ \\
\hline Sales/sales supervision & $\begin{array}{c}12 \\
14.1\end{array}$ & $\begin{array}{c}9 \\
6.4\end{array}$ \\
\hline Service & $\begin{array}{c}8 \\
9.4\end{array}$ & $2^{3} .1$ \\
\hline Nursing-Lab technology & $\begin{array}{l}0 \\
0\end{array}$ & $\begin{array}{c}4 \\
2.9\end{array}$ \\
\hline Artistic-Literary & $\begin{array}{c}1 \\
1.2\end{array}$ & $\begin{array}{c}5 \\
3.6\end{array}$ \\
\hline Other & $\begin{array}{c}13 \\
15.3\end{array}$ & $\begin{array}{c}5 \\
3.6\end{array}$ \\
\hline
\end{tabular}

was essential. These findings indicate that the majority of alumni who entered this line of work were in direct competition with people who did not have a degree, and were given a competitive edge by having one.

A similar, but less extreme, situation was encountered by those respondents who got work in psychotechnology. Here a higher percentage believed that the possession of a degree helped them to get work in the field, and close to half of them indicated that a social science degree was essential for employment. To a greater extent, then, alumni who obtained employment in this area were able to match their credentials with job specifications. At the same time, sight must not be lost of the fact that slightly over half of them found themselves competing with job applicants who did not have a university degree.

It is interesting to note that while only $23 \%$ of the business managers anticipated getting that type of job, $86 \%$ of them reported that they were either satisfied or somewhat satisfied with it. In contrast, $53 \%$ of the psychotechnologists anticipated getting the job that they got, with $85 \%$ of them being to some extent satisfied with it. This contrast is one indication that a major career shift at the time of graduation need not end in job dissatisfaction.

As would be expected, the match between training and job specifications was highest for the teachers. The question of interest here was why the percentage of respondents who indicated that a degree was essential for getting the job was not higher than the 
Table 3

Usefulness of the degree*

\begin{tabular}{|c|c|c|c|c|c|c|c|c|c|c|}
\hline & & Teach. & $\begin{array}{l}\text { Bus. / } \\
\text { mgmt. }\end{array}$ & $\begin{array}{l}\text { Sec./ } \\
\text { cler. }\end{array}$ & $\begin{array}{l}\text { Psy. } / \\
\text { tech. }\end{array}$ & Sales & Serv. & $\begin{array}{l}\text { Nrsg/ } \\
\text { lab }\end{array}$ & $\begin{array}{l}\text { Art/ } \\
\text { lit. }\end{array}$ & other \\
\hline \multirow[t]{2}{*}{$\begin{array}{l}\text { Present job } \\
\text { career oriented? }\end{array}$} & Yes & $\begin{array}{l}46 \\
95.8 \%\end{array}$ & $\begin{array}{l}27 \\
75.0 \%\end{array}$ & $\begin{array}{l}10 \\
35.7 \%\end{array}$ & $\begin{array}{l}36 \\
69.2 \%\end{array}$ & $\begin{array}{l}17 \\
81.0 \%\end{array}$ & $27^{3} \cdot 3 \%$ & $100^{4} .0 \%$ & $100.0 \%$ & $41.2 \%$ \\
\hline & No & $\begin{array}{l}2 \\
4.2\end{array}$ & $\begin{array}{c}9 \\
25.0\end{array}$ & $\begin{array}{c}18 \\
64.3\end{array}$ & $\begin{array}{c}16 \\
30.8\end{array}$ & 19.0 & $\begin{array}{c}8 \\
72.7\end{array}$ & $\begin{array}{c}0 \\
0.0\end{array}$ & $\begin{array}{c}0 \\
0.0\end{array}$ & $\begin{array}{c}10 \\
58.8\end{array}$ \\
\hline \multirow{2}{*}{$\begin{array}{l}\text { Job require } \\
\text { psychological } \\
\text { skills? }\end{array}$} & Yes & $\begin{array}{l}46 \\
95.8\end{array}$ & $\begin{array}{l}22 \\
61.1\end{array}$ & $\begin{array}{c}7 \\
25.0\end{array}$ & $\begin{array}{c}40 \\
76.9\end{array}$ & $\begin{array}{c}12 \\
57.1\end{array}$ & $\begin{array}{c}2 \\
18.2\end{array}$ & $\begin{array}{c}4 \\
100.0\end{array}$ & $66^{4} .7$ & 35.3 \\
\hline & No & $\stackrel{2}{4.2}$ & $\begin{array}{c}14 \\
38.9\end{array}$ & $\begin{array}{c}21 \\
75.0\end{array}$ & $\begin{array}{c}12 \\
23.1\end{array}$ & $42^{9} .9$ & $\begin{array}{c}9 \\
81.8\end{array}$ & $\begin{array}{r}0 \\
0.0\end{array}$ & $\begin{array}{c}2 \\
33.3\end{array}$ & $\begin{array}{c}11 \\
64.7\end{array}$ \\
\hline \multirow[t]{2}{*}{$\begin{array}{l}\text { Degree help to } \\
\text { get job? }\end{array}$} & Yes & $\begin{array}{c}40 \\
83.3\end{array}$ & $\begin{array}{c}23 \\
63.9\end{array}$ & $\begin{array}{c}12 \\
44.4\end{array}$ & $\begin{array}{c}41 \\
78.8\end{array}$ & $\begin{array}{c}12 \\
57.1\end{array}$ & $\begin{array}{c}3 \\
27.3\end{array}$ & $\stackrel{2}{50.0}$ & 50.0 & $\begin{array}{c}6 \\
35.3\end{array}$ \\
\hline & No & $\begin{array}{c}8 \\
16.7\end{array}$ & $\begin{array}{c}13 \\
36.1\end{array}$ & 55.6 & $\begin{array}{c}11 \\
21.2\end{array}$ & $\begin{array}{c}9 \\
42.9\end{array}$ & 72.7 & 50.0 & $\begin{array}{l}3 \\
50.0\end{array}$ & $\begin{array}{c}11 \\
64.7\end{array}$ \\
\hline \multirow[t]{2}{*}{$\begin{array}{l}\text { Degree essential } \\
\text { for job? }\end{array}$} & Yes & $\begin{array}{c}35 \\
72.9\end{array}$ & $\begin{array}{c}10 \\
27.8\end{array}$ & $\begin{array}{c}1 \\
3.7\end{array}$ & $\begin{array}{c}25 \\
48.1\end{array}$ & $14^{3} \cdot 3$ & $\begin{array}{l}0 \\
0.0\end{array}$ & $\begin{array}{c}0 \\
0.0\end{array}$ & $\stackrel{0}{0.0}$ & $18^{3} .7$ \\
\hline & No & $\begin{array}{c}13 \\
27.1 \\
\end{array}$ & $\begin{array}{c}26 \\
72.2 \\
\end{array}$ & $\begin{array}{c}26 \\
96.3 \\
\end{array}$ & $\begin{array}{c}27 \\
51.9 \\
\end{array}$ & $\begin{array}{c}18 \\
85.7 \\
\end{array}$ & $\begin{array}{c}11 \\
100.0\end{array}$ & $\begin{array}{c}4 \\
100.0 \\
\end{array}$ & $\begin{array}{c}6 \\
100.0 \\
\end{array}$ & $\begin{array}{c}13 \\
81.3 \\
\end{array}$ \\
\hline \multirow[t]{2}{*}{$\begin{array}{l}\text { Social Science } \\
\text { degree essential? }\end{array}$} & Yes & $\begin{array}{c}14 \\
29.2\end{array}$ & 11.1 & 3.7 & $\begin{array}{l}25 \\
48.1\end{array}$ & $\frac{1}{4.8}$ & 0 & $\begin{array}{c}0 \\
0.0\end{array}$ & $\begin{array}{c}0 \\
0.0\end{array}$ & $\begin{array}{c}1 \\
5.9\end{array}$ \\
\hline & No & $\begin{array}{c}34 \\
70.8 \\
\end{array}$ & $\begin{array}{r}32 \\
88.9 \\
\end{array}$ & $\begin{array}{c}26 \\
96.3 \\
\end{array}$ & $\begin{array}{r}27 \\
51.9 \\
\end{array}$ & $\begin{array}{r}20 \\
95.2 \\
\end{array}$ & $\begin{array}{c}1 I \\
100.0\end{array}$ & $\begin{array}{r}4 \\
100.0 \\
\end{array}$ & $\begin{array}{c}6 \\
100.0 \\
\end{array}$ & $\begin{array}{r}16 \\
94.1 \\
\end{array}$ \\
\hline \multirow[t]{2}{*}{$\begin{array}{l}\text { Job the type } \\
\text { anticipated? }\end{array}$} & Yes & $\begin{array}{c}35 \\
74.5\end{array}$ & 22.9 & $\begin{array}{c}2 \\
7.4\end{array}$ & $\begin{array}{c}27 \\
52.9\end{array}$ & 30.0 & $\begin{array}{c}1 \\
9.1\end{array}$ & ${ }^{3}$ & $33^{2} .3$ & $\begin{array}{c}5 \\
29.4\end{array}$ \\
\hline & No & $\begin{array}{c}12 \\
25.5\end{array}$ & $\begin{array}{c}27 \\
77.1\end{array}$ & $\begin{array}{c}25 \\
92.6\end{array}$ & $\begin{array}{c}24 \\
47.1\end{array}$ & $\begin{array}{c}14 \\
70.0\end{array}$ & $\begin{array}{c}10 \\
90.9\end{array}$ & $\begin{array}{c}1 \\
25.0\end{array}$ & $66^{4} .7$ & $\begin{array}{c}12 \\
70.6\end{array}$ \\
\hline
\end{tabular}

*The $x^{2}$ value for every question is highly significant

Table 4

Job Satisfaction

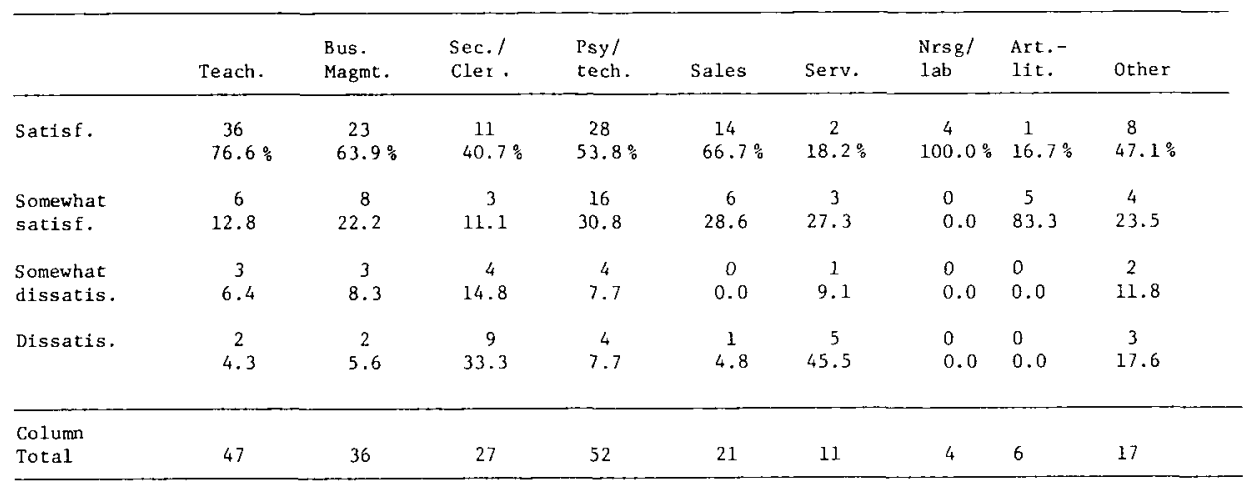


Table 5

Present Salary Means and Standard Deviations

in Thousands of Dollars

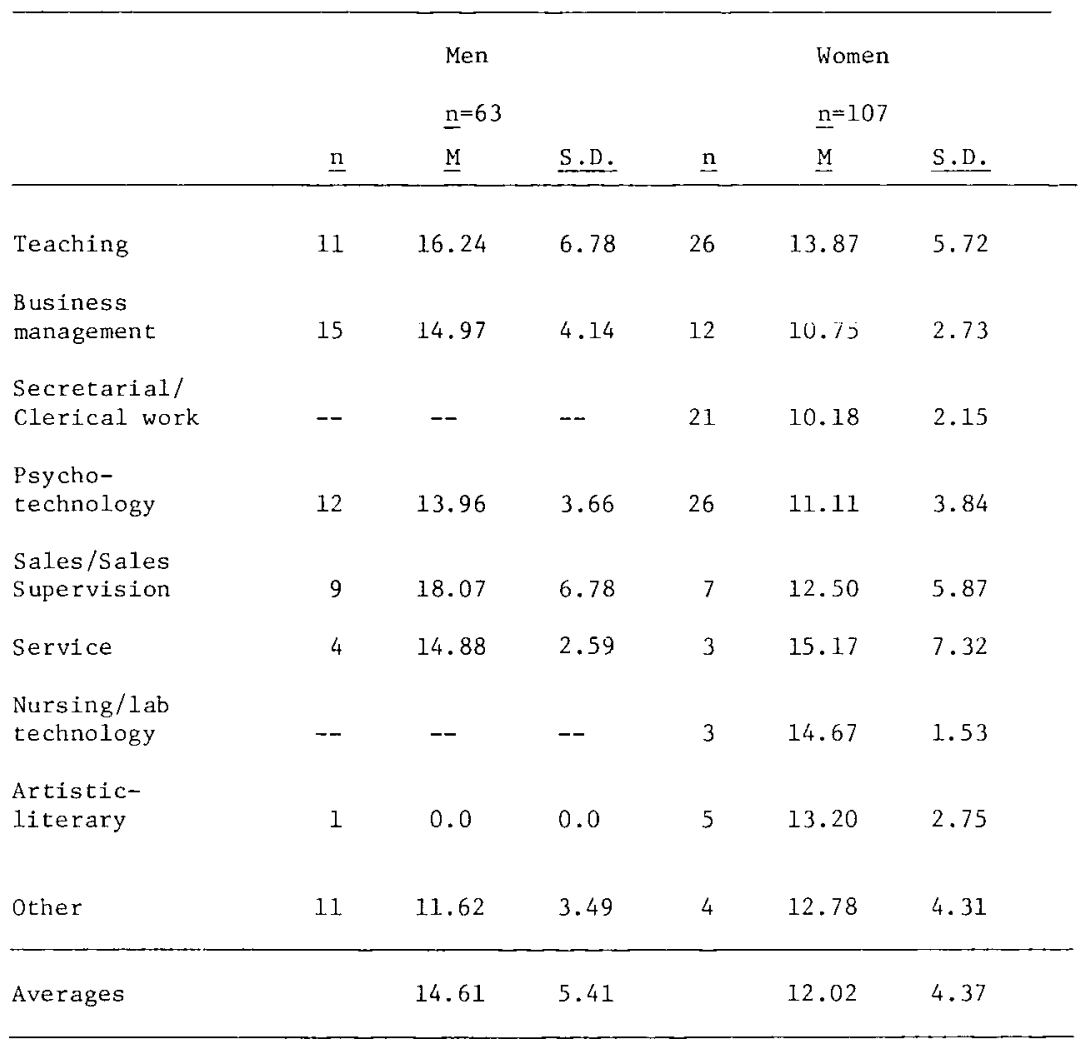

obtained value of $73 \%$. One possibility is that some of these alumni got jobs as teachers in private schools that did not require a degree as a condition of employment. Another possibility is that some of these respondents were teachers on leaves-of-absence who had secured their jobs during a time when possession of a degree was not a condition of employment. One finding of interest about the teachers that is not reported in the tables was that $36 \%, 21 \%$ and $17 \%$ of the female 1976,1977 and 1978 graduates, respectively, obtained jobs as teachers. This trend is consistent with the declining enrolment faced by Toronto schools in the late nineteen seventies.

(e) Salaries. The distribution of salaries across the nine job categories is reported in Table 5 . The average salary of all respondents who gave salary information was $\$ 12,980$, and the mean salary for the men was $\$ 14,610$ in contrast with $\$ 12,020$ for the women. This discrepancy is difficult to interpret. In some instances, the job categories subsume a variety of jobs and it is possible that the men opted for higher paying types of occupations within a category than did the women. Also, the men were older than the women and may have had greater job experience to bring to the jobs obtained after graduation. At the same time, the possibility that salary discrimination against women was operating here cannot be ruled out. 
Type of Education Taken After Bachelor's Degree (Tabulated by Type of Degree)

\begin{tabular}{|c|c|c|c|c|}
\hline & \multicolumn{2}{|c|}{$\begin{array}{l}\text { Ordinary } \\
\text { Degree }\end{array}$} & \multicolumn{2}{|c|}{$\begin{array}{r}\text { Honours } \\
\text { Degree }\end{array}$} \\
\hline & $\begin{array}{c}M \\
\mathrm{n}\end{array}=39$ & $\begin{array}{l}\mathrm{W} \\
\mathrm{n}\end{array}=44$ & $\begin{array}{c}M \\
\underline{\mathbf{n}}=26\end{array}$ & $\begin{array}{c}\mathrm{W} \\
\underline{\mathrm{n}}=27\end{array}$ \\
\hline $\begin{array}{l}\text { Further training at } \\
\text { the Bachelor's level }\end{array}$ & $\begin{array}{c}10 \\
25.6 \%\end{array}$ & $\begin{array}{l}14 \\
31.8 \%\end{array}$ & $11.5 \%$ & $\begin{array}{c}7 \\
25.9 \%\end{array}$ \\
\hline Education (grad.) & $\begin{array}{c}3 \\
7.7\end{array}$ & 11.4 & $7^{2} .7$ & $\stackrel{2}{7.4}$ \\
\hline Psychology & $10^{4} 3$ & $\begin{array}{c}3 \\
6.8\end{array}$ & $\begin{array}{c}14 \\
53.8\end{array}$ & $\begin{array}{c}8 \\
29.6\end{array}$ \\
\hline Social Work & $\begin{array}{c}1 \\
2.6\end{array}$ & $\begin{array}{c}6 \\
13.6\end{array}$ & $\begin{array}{l}1 \\
3.8\end{array}$ & $\begin{array}{c}2 \\
7.4\end{array}$ \\
\hline $\begin{array}{l}\text { Other graduate } \\
\text { programmes }\end{array}$ & $\begin{array}{c}4 \\
10.2\end{array}$ & $\begin{array}{c}5 \\
11.4\end{array}$ & $\begin{array}{c}2 \\
7.7\end{array}$ & $\begin{array}{c}4 \\
14.8\end{array}$ \\
\hline Dentistry/Medicine & $\begin{array}{c}2 \\
5.1\end{array}$ & $\begin{array}{l}2 \\
4.5\end{array}$ & $\begin{array}{c}1 \\
3.8\end{array}$ & $\begin{array}{l}1 \\
3.7\end{array}$ \\
\hline $\mathrm{Law} / \mathrm{MBA}$ & $\begin{array}{c}4 \\
10.2\end{array}$ & $\begin{array}{c}1 \\
2.3\end{array}$ & $\begin{array}{c}1 \\
3.8\end{array}$ & $\begin{array}{l}0 \\
0\end{array}$ \\
\hline Teaching & $\begin{array}{c}2 \\
5.1\end{array}$ & 9.1 & $\begin{array}{c}1 \\
3.8\end{array}$ & $\begin{array}{l}1 \\
3.7\end{array}$ \\
\hline $\begin{array}{l}\text { Other professional } \\
\text { school }\end{array}$ & $\begin{array}{c}5 \\
12.8\end{array}$ & $\begin{array}{c}1 \\
2.3\end{array}$ & $\begin{array}{l}0 \\
0\end{array}$ & $\begin{array}{l}0 \\
0\end{array}$ \\
\hline Certificate/Diploma & $\begin{array}{c}4 \\
10.3\end{array}$ & $\begin{array}{l}3 \\
6.8\end{array}$ & $\begin{array}{c}1 \\
3.8\end{array}$ & $\begin{array}{c}2 \\
7.4\end{array}$ \\
\hline
\end{tabular}

\section{Further training}

It was found that of the 325 individuals sampled, $48.1 \%$ of the men and $37.3 \%$ of the women took further training after the Bachelor's degree in psychology. Table 6 summarizes the types of further training taken by the respondents. When both sexes are combined, it can be seen that $66(20.3 \%)$ of the sample went on to graduate school, $12.9 \%$ took further training at the Bachelor's degree level (including the Bachelor of Education degree) ${ }^{3}$, and that smaller numbers took advanced training in the professions, or obtained a certificate or diploma from a community college.

There was some evidence that men chose different paths of further training than did women, at least in some categories. Among those who took further training, $18(27.7 \%)$ of the men went on to graduate work in psychology, in contrast with $15.5 \%$ of the women. On the other hand $3.1 \%$ of the men took graduate work in social work in comparison with $11.3 \%$ of the women. Earlier it was seen that, among those alumni who were in the labour force at the time of the survey, there were proportionately more women than men employed as psychotechnologists. The broad picture, then, is that approximately the 
same proportion of men as women pursued careers in the application of psychology to human service, but that the expression of this application differed somewhat between the sexes. The women in the sample tended either to enter the labour force in this area without taking further training beyond the Bachelor's degree, or to take graduate training in social work. In contrast, the men had a greater tendency to take training to become professional psychologists. The author can only speculate as to why this was the case. One possibility is that obtaining a doctorate in psychology requires a large investment of time and energy, and it is an investment that would seem hardly worthwhile unless one were prepared to make a lifetime career of psychology. The common definition of sex roles in society may have made it easier for men than for women to make this choice.

It was found that $45.7 \%$ of the psychology alumni with an Honours degree went on to further training, in comparison with $39.7 \%$ of those with an Ordinary degree. This overall pattern was similar among the men and the women. However, for the men there were some marked differences within categories of further training as a function of the type of degree. As can be seen from Table 6, men with an Ordinary degree tended to concentrate more heavily on further training at the Bachelor's degree level, or to enrol in a professional school, whereas proportionately more men with an Honours degree went on to graduate school in psychology. Such differences were not as pronounced among the women.

It is noteworthy in Table 6 that 16 respondents with an Ordinary degree got into psychology and other graduate programmes, exclusive of social work. This would appear to raise questions about the admissions standards of certain graduate schools, since an Honours degree is generally considered to be requisite for admission, at least at most graduate programmes in Canada.

\section{DISCUSSION}

The representativeness of the sample is of paramount concern in survey research. In the present study, approximately $43 \%$ of the sample were contacted by telephone. Very few of those contacted refused to be interviewed, which removed one large source of selection bias. An additional $12 \%$ of the sample were contacted through the postal service, which means that only about one-fifth of those alumni whom we attempted to reach through the mail responded to the questionnaire. The resulting $55 \%$ contract-rate is better than obtained through most mail surveys (e.g., Ralston (1978) got responses from $47 \%$ of her sample) but inferior to the $71 \%$ rate (for Ontario) achieved by Statistics Canada.

The results indicated that the employment rates of the 1976-78 psychology bachelors were similar to national, provincial and local indices. Only the rate of the 1978 male graduates was outstandingly low. Other surveys have shown that it takes a period of time for university graduates to achieve high rates of employment after graduating (Statistics Canada, 1978b; Stewart, Olesiuk, Coates, \& White, Note 2). It is likely that the result for the 1978 male alumni is either a reflection of that process or of the process combined with sampling error (the rate was based on a work force of 38 men).

It was found that, while the unemployment rate for these 1978 male graduates was significantly higher than the national average, the rates for the 1976-78 female graduates and for the 1976-77 male graduates were not significantly different from the Toronto rates against which they were compared. It is important to note that the term "significant" as used here means statistical significance. The unemployment rate among the 1976 and 1977 York male alumni was less than $3.6 \%$, which is close to the national average for university 
graduates irrespective of when they graduated. However, the sample sizes in the present study were rather small which resulted in correspondingly large standard errors of estimate. Hence, for the majority of the present samples, the obtained unemployment rates, although low, were not sufficiently low to allow one to conclude that they were statistically significantly smaller than the rates for Torontonians of all educational attainment levels who were the same age as the respondents.

further training did so either in graduate or professional schools. Furthermore, two-thirds of those entering the work force secured jobs in either psychotechnology, teaching, or business management. To a certain extent there is overlap between those who went on to further training and those who got these jobs. Nevertheless, it can be said that the majority of B.A. and B.Sc. degree holders either secured jobs in the above three job categories or entered a professional career path by going on to graduate school or a professional school. Related to this is the finding that the job satisfaction expressed by those in these and most other job categories was quite high. Hence, the broad picture depicts a reasonably healthy situation for the graduates in this competitive time.

One of the reasons the author did this study was to discover to what extent psychology Baccalaureates actually get work that allows them to apply their psychological training. In obtaining this work, they have to compete with community college graduates in child care work, rehabilitation counselling and social casework technology, with graduates from social work programmes from several universities, and with M.A. level psychology graduates. Furthermore, federal and provincial austerity programmes have had an impact on the number of job openings.

Against this background, the finding that $23 \%$ of the respondents in the labour force got jobs as psychotechnologists is the kind of finding that could be interpreted by skeptics that the chance of getting into "the helping professions" with a B.A. is rather slim, and by optimists that the chance is fair to good. Qualitative remarks by some of the respondents indicated that entry into the field was difficult and sometimes required taking interim jobs during the search. A number of respondents got work in an agency as a result of having done field work there as part of their undergraduate training. Overall, it would appear that the social service sector in Southern Ontario is currently fairly impervious to entry by Bachelor's degree graduates in psychology but that penetration can be made with considerable diligence and patience. Certainly the situation is different than that reported by Ralston (1978) who found that $62 \%$ of St. Mary's University sociology Baccalaureates who graduated between 1971 and 1977, and who did not take further training, got jobs in social welfare agencies. Here we have a different jurisdiction (Nova Scotia), with a different educational system (no community colleges), and a different time frame (1971-77 as opposed to 1976-78).

We can also look at the findings of the present survey in terms of their implications for university programming. One striking finding is that, while the majority of respondents considered that the possession of a university degree was an asset in getting their jobs and the large majority of respondents were at least somewhat satisfied with the jobs they did get, in some instances a large percentage of the respondents also indicated that if they had a chance to do it over again, they would have taken different training. This was particularly evident for the business management, sales/salesmanagement and clerical groups, which accounted for almost two-fifths of the alumni who were working. This finding suggests that undergraduates in psychology should be alerted to the opportunities in the corporate world and to courses in economics, business, accounting and computer science that would be congruent with a path in that direction. 
This expansion in new directions is becoming more critical, particularly as access to teaching as a profession becomes increasingly difficult, at least in Ontario, as the public and secondary schools in the province face declining enrolments. Future graduates in psychology will by necessity have to diversify their career choices to a somewhat greater extent than was true of alumni preceding them.

This prospect need not be faced with alarm by current and future students in psychology. The present survey showed that, with the exception of clerical and service workers, the job satisfaction rates were high even though many respondents got jobs that they did not anticipate getting. This suggests that graduates are flexible and capable of accommodating their interests and values to unexpected vocational situations. At the same time, the transition for those who find job opportunities that are discrepant with their expectations could be eased if efforts by the university faculty and administrators were made to make undergraduates more aware of the job opportunities that actually exist and to develop programmes which simultaneously protect traditional academic values and orient students to the world outside the university.

\section{Reference Notes}

1. Anisef, P., \& Jansen, C. York graduate study VI - Present work experiences. Research report, York University, Institute for Behavioural Research, October, 1972.

2. Stewart, J., Olesiuk, K., Coates, D., \& White, C. Report on the 1973 survey of York University graduates. York University, 1976.

\section{REFERENCES}

Kerlinger, F.N. Foundations of behavioral research. Second edition. New York, Holt, Rinehart and Winston, 1973.

Ralston, $\mathbf{H}$. The uses of a Bachelor's degree in sociology: Careers of recent graduates from a Maritime university. The Canadian Journal of Higher Education, 8, 1978, 47-66.

Statistics Canada. Employment of 1976 university and college graduates. Report No. 4-2212-520, 1978(a).

Statistics Canada. The labour force, 34, Nos. 7, 8, and 9 (1978) and 35, Nos. 2, 3, and 5, 1979(b).

The Globe and Mail. "The fading dream: Children of baby boom try to keep job hopes alive", December 1, 1979.

\section{Footnotes}

1. The B.Sc. graduates were in the extreme minority in the population, and no attempt was made to determine if their career outcomes differed from those of B.A. graduates.

2. The standard error of the difference between sample proportions was calculated according to the formula $\mathrm{SE}_{\mathrm{prop}}=\sqrt{\frac{\mathrm{pq}}{\mathrm{N}}}$, where $p$ is the proportion of unemployment in the population, $q$ is the proportion of employed, and $N$ is the size of the sample.

3. York offers a 5-year Combined Honours programme in psychology and education. Students who take this programme graduate with a B.A. and a B.Ed. degree. It appears that some of the respondents in the survey who were in the combined programme did not report that they took further training after their B.A. degree. Alternatively, those respondents who took a B.A. and then went on to an education programme reported that they did take further training beyond the B.A. This anomaly explains the large discrepancy between the number of respondents who entered teaching as a career and the number who reported getting a Bachelor of Education degree. 